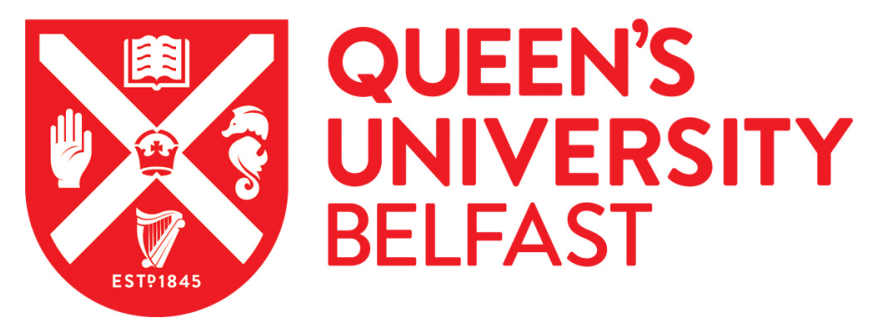

\title{
REASSESSING THE POLISH BRETHREN ON MAGISTRACY, PACIFISM, AND WARFARE IN THE SEVENTEENTH CENTURY
}

Quatrini, F. (2020). REASSESSING THE POLISH BRETHREN ON MAGISTRACY, PACIFISM, AND WARFARE IN THE SEVENTEENTH CENTURY. Historical Journal. https://doi.org/10.1017/S0018246X20000485

Published in:

Historical Journal

Document Version:

Peer reviewed version

Queen's University Belfast - Research Portal:

Link to publication record in Queen's University Belfast Research Portal

\section{Publisher rights}

Copyright 2020 the Authors.

This manuscript is distributed under a Creative Commons Attribution-NonCommercial-NoDerivs License

(https://creativecommons.org/licenses/by-nc-nd/4.0/), which permits distribution and reproduction for non-commercial purposes, provided the author and source are cited..

\section{General rights}

Copyright for the publications made accessible via the Queen's University Belfast Research Portal is retained by the author(s) and / or other copyright owners and it is a condition of accessing these publications that users recognise and abide by the legal requirements associated with these rights.

Take down policy

The Research Portal is Queen's institutional repository that provides access to Queen's research output. Every effort has been made to ensure that content in the Research Portal does not infringe any person's rights, or applicable UK laws. If you discover content in the Research Portal that you believe breaches copyright or violates any law, please contact openaccess@qub.ac.uk. 
Reassessing the Polish Brethren on Magistracy, Pacifism, and Warfare in the Seventeenth Century*

\section{Francesco Quatrini}

\section{Queen's University Belfast}

Abstract. The Polish Brethren, usually known as Socinians, were perhaps the most infamous Christian sect belonging to the so-called 'Radical Reformation'. Renowned for their antiTrinitarian beliefs and their rationalistic approach towards religion, the Brethren discussed also theological-political concepts such as the legitimacy of magistracy and warfare. Relevant literature on the Brethren’s socio-political views underestimate the Brethren's participation in contemporary debates on the ius belli, describing them as pacifists who generally opposed politics and violence until the 1650s, when some of them began defending a more conventional approach towards magistracy and warfare. The article proves that this shift toward a more standard Protestant position occurred as early as the 1620s, when Johannes Crell and Jonas Szlichtyng, two of the most prominent spokespersons among the Brethren, reconciled politics and the Brethren's faith in their writings. The article highlights how the very historical situation of the Polish-Lithuanian Commonwealth urged them to revise their views on magistracy and warfare, and it argues that they were assisted in this by their education in European universities, especially the Lutheran Academy of Altdorf near Nuremberg, which provided them with different perspectives on the legitimacy of defensive warfare.

The sixteenth and seventeenth centuries were deeply marked by religious warfare. Almost permanent conflict with the Turkish Empire, colonial attacks against the heathens and idolaters of non-European countries, and strife among Christian sects kept alive a doctrine of holy war 
that could mobilize large numbers of believers. At the same time, this gradually enabled the development of a common and inter-confessional ideology of just war. ${ }^{1}$ Indeed, these centuries witnessed the development of a large literature on the ius belli, 'the right of war', which included discussions on the ius ad bellum - legitimate reasons to wage a war - and the ius in bello - legitimate ways to fight a war. While many rejected the use of force and war to impose religious beliefs on others, justifications of the use of force to defend oneself, one's goods, or one's country were quite common among all European intellectuals, regardless of their confession of faith. These justifications were mostly based on the Roman law of self-defence, vim vi repellere, which means 'to repel force through force' and was generally regarded as a natural law. This very natural law was also the main basis upon which resistance to tyrants or sovereigns that were not regarded as legitimate for either religious or political reasons could be justified. $^{2}$

Nevertheless, some Christian minorities - such as the Dutch Mennonites and the Anabaptist Moravian Brethren - did not adopt this mainstream approach toward self-defence and warfare. Believing that the natural law vim vi repellere was contrary to Christ's teaching, they completely rejected any use of force and denied the legitimacy of warfare, embracing a broad pacifism instead. Pacifism can be broadly defined as a practical and intellectual devotion to peace and opposition to war, which includes 'a variety of commitments on a continuum from an absolute adherence to nonviolence in all actions to a more focused or minimal sort of antiwarism'. ${ }^{3}$ The Polish Brethren - whom scholars in the field refer to as Socinians, from the name of the Italian scholar Fausto Sozzini (Faustus Socinus; 1539-1604) - were among these minorities. $^{4}$

In this paper, I examine the development of the Brethren's views when addressing three essential questions: is it legitimate for a Christian to hold a public office such as lesser or supreme magistrate? If so, is it legitimate for a Christian magistrate to condemn someone to 
the death penalty and to wage wars against other nations? Finally, is it legitimate for private Christians to participate in wars? In describing the Brethren's answers to these questions, the main goal of this paper is reassessing precisely when it was that the Brethren reconsidered their pacifist approach to magistracy and warfare. Indeed, it is usually accepted that the Brethren discarded their original pacifist ideas in the late 1640s or 1650s, thanks to the works of Jonas Szlichtyng (or Schlichting; 1592-1661) and Samuel Przypkowski (1592-1670). Janusz Tazbir, for instance, described the Brethren’s ‘socio-political programme’ as ‘marked by an unfriendly or even hostile attitude to the state and to all forms of violence and oppression, including war'. Referring to Szlichtyng's treatise published against the Lutheran theologian Balthasar Meisner, Tazbir then asserted that in 1636, Szlichtyng was still maintaining 'that even though the state had the power to punish people by death and to conduct wars, a true Christian should have nothing to do with this'. Tazbir relied on Stanislas Kot's fundamental study of the Brethren's socio-political views, which indeed argued that Szlichtyng turned away from the early pacifism of his church only in the late 1640s, a conclusion shared by Peter Brock as well. ${ }^{5}$ Being well established that the Brethren changed their socio-political views in the course of the seventeenth century, it then becomes fundamental to know precisely in which sense they changed these views and when this occurred. The analysis of primary sources offered in this paper is intended precisely for this purpose and by contrast, proves that Szlichtyng had developed different views by the time he replied to Meisner in 1636, allowing Christian magistrates to wage defensive wars and private Christians to participate in them. Moreover, Szlichtyng was assisted in this by his friend and mentor Johannes Crell (1590-1633), who had developed a much more standard position on magistracy and Christianity already in $1623 .{ }^{6}$ The Brethren were thus beginning to abandon their pacifism twenty years earlier than historians have previously noted. 
A thorough examination of the reasons that pushed Crell and Szlichtyng to change their views on magistracy and warfare is beyond the scope of this paper. In the following, however, I will suggest two likely causes. First, the active participation of the Polish-Lithuanian Commonwealth in several wars from the early seventeenth century onwards. Second, the growing openness of the second generation of Brethren towards the intellectual European milieu. From the early 1600s onwards, young Brethren went abroad to attend famous academies and universities, especially the Lutheran Academy of Altdorf near Nuremberg. This provided the Brethren with new and different perspectives on philosophical, theological, and political matters. In this paper, I will particularly focus on the Academy of Altdorf. Indeed, as highlighted by Sarah Mortimer, the second generation of Socinians educated at the University of Altdorf played a fundamental role in re-shaping the Brethren's theology in the seventeenth century. ${ }^{7}$ In Altdorf, these same Brethren met also scholars holding and teaching ideas on magistracy and warfare quite different from those defended by Socinus and the Brethren forefathers, and this certainly made the young Brethren aware of the broader inter-confessional European debates on the ius belli, in which they would take active part from the 1620s onward.

\section{I}

The Polish Brethren were members of the Minor Reformed Church of Poland, which flourished in the Polish-Lithuanian Commonwealth until 1658. This church originated around 1563, when the Polish Reformed Church split into two groups because of the anti-Trinitarian views embraced by some of its adherents. ${ }^{8}$ The Brethren are renowned today for their anti-Trinitarian beliefs; their principle of applying natural reason to interpret the Scriptures and religious dogmas; and their advocacy of freedom of religion and toleration. ${ }^{9}$ Mortimer has also rightly emphasized that the 'insistence upon the role of human beings in their own salvation' and the 
‘commitment to Christianity as a religion of supernatural rewards and stringent ethics' were other common beliefs among the Brethren. ${ }^{10}$ These were the same doctrines that made them increasingly (in)famous throughout sixteenth- and seventeenth-century Europe. However, it can be hardly said that they were a homogenous group. Differences about other theological beliefs and socio-political views arose as soon as the Minor Church was established. ${ }^{11}$ For instance, they often debated whether Christ should be adored as divine, even if he was only a human being, or whether Adam was mortal before the fall. ${ }^{12}$ The relationship between politics and the Christian religion was one of the most controversial. The controversies concerned two main inter-related subjects. Firstly, the relationship between private Christianity and secular power, which included discussions on: whether Christians could hold civil offices as sovereign or as lesser magistrates, whether Christians could exercise the right to inflict corporal punishments and the death penalty (or ius gladii, 'the right of the sword') when holding these offices, and whether Christians could appeal to magistrates for justice. Secondly, the relationship between the Christian religion and the natural law vim vi repellere, which included disputes on the legitimacy of private self-defence and of warfare to defend one's country.

It is possible to distinguish two main parties involved in these controversies. On the one hand, there were those who denied that Christians could actively participate in civil life. As the Christian religion is not of this world, true believers should not hold public offices or take part in wars, even defensive ones. Rejecting the law vim vi repellere as contrary to the Christian religion, they also argued that true Christians should not defend themselves when attacked, but rather they should run away or endure the assault, even accepting death. On the other hand, other Brethren held a more standard position on the relationship between Christian religion and politics, allowing the existence of Christian magistrates and participation in defensive wars. They also allowed private self-defence, even if some of them stressed that one should at least try not to kill his or her attacker. These discussions on magistracy and warfare were particularly 
relevant for the Brethren. Since its very beginning, the Minor Church managed to gain the support of some noblemen and members of the gentry who had a legal duty to join the army personally in case of war. If they failed to do so and disobeyed the order of the King without a justifiable excuse, their property would be confiscated and they would be deprived of the privileges connected with their noble status. ${ }^{13}$

It should be emphasized that the pacifist Brethren did not deny political authority per se, as many of their opponents accused them of doing. They rather denied that those holding civil offices - be they sovereigns or lesser magistrates - could be true Christians. They believed in a (perhaps utopian) complete separation from all that belonged to the ordinary civil and political life. Over the sixteenth century, support among the Brethren gradually shifted towards the pacifist party. Faustus Socinus contributed much to their success. ${ }^{14}$ In his last years, Socinus slightly modified his views, allowing Christians to hold public offices and to bear arms. At the same time, he was still arguing that Christians must absolutely refrain from killing anyone, be they private citizens or public magistrates. Moreover, he carefully avoided examining whether a Christian magistrate can justly wage a war to defend his or her country. ${ }^{15}$ In 1614 , Valentin Schmalz (or Smalcius; 1572-1622) made his views on these questions much more clear, when replying to the Lutheran Wolfgang Franz. ${ }^{16}$ According to Smalcius, Christians are allowed to hold public offices and a Christian magistrate has the same ius gladii that non-Christian magistrates have, but he should use this right with moderation, avoiding the most severe punishments whenever he can. Moreover, a Christian magistrate can never sentence someone to death, because 'it is not legitimate for the Christian magistrate to shed blood'. This does not mean to detract from the magistrate, Smalcius states, as 'it is legitimate for the magistrate to repress criminals through other means that are perhaps more severe than the shedding of blood'. ${ }^{17}$ This unconditional prohibition of killing other human beings naturally affected Smalcius’s views on wars. Casting aside Socinus's ambiguities, Smalcius writes that 'we deny 
that it is legitimate to wage war and we affirm earnestly that it is unworthy of the Christian piety'. ${ }^{18}$ He does not even allow wars to defend one's country. There are different means to avoid a war, Smalcius says, and when it is impossible to prevent it, then the sovereign should rather opt for a spontanea deditio, 'a voluntary surrender'. ${ }^{19}$

Although Smalcius was still restraining the rights of Christian magistrates and denying the legitimacy of defensive wars, the intellectual atmosphere in Raków was likely changing. Two reasons can be suggested for this gradual change. First, the Polish-Lithuanian Commonwealth was almost continuously at war in the first three decades of the seventeenth century. ${ }^{20}$ This included severe attacks from the Ottoman Empire and Muscovy, as well as the war against Sweden (1626-29) and the Smoleńsk War (1632-4). ${ }^{21}$ At the beginning of the seventeenth century, the Commonwealth had to face the Zebrzydowski rebellion as well (160609), a brief civil war prompted by members of the Polish gentry who saw their political liberties threatened by king Sigismund III Vasa. ${ }^{22}$ The Brethren did not remain indifferent to such conflicts, as their pacifist attitude would have required them to do. Jakub Sienieński, patron and protector of Raków, joined the Zebrzydowski rebellion. ${ }^{23}$ Moreover, Brethren belonging to the nobility or the gentry actively participated in the aforementioned and subsequent wars, distinguishing themselves in battle. For instance, prominent Brethren families such as Moskorzowski and Przypkowksi fought on king Władysław IV’s side at Smoleńsk. ${ }^{24}$ The Brethren’s synods at Raków in 1604 and 1605 even passed specific resolutions allowing the resistance against the Tatars who had invaded Podolia. ${ }^{25}$ This proves that there was a clear dichotomy between the pacifist doctrines as defended by leaders such as Socinus and Smalcius and the practical historical situation the Brethren had to face. A reconciliation between their ideas on warfare, their need to defend themselves, and their duty to participate in the Polish wars was therefore required. The fact that the second generation of Brethren showed themselves much more keen to participate in wider European debates favoured such a 
reconciliation, and this is the second reason why the Brethern adopted a new approach to politics and warfare. Indeed, when developing more conventional ideas on these subjects, Brethren such as Crell and Szlichtyng came closer to the standard Protestant thinking on politics and religion, a tradition that they first encountered personally at the Academy of Altdorf during their formative years.

\section{II}

The Lutheran Academy of Altdorf near Nuremberg, known as Academia Norica, was the main centre in the German territories from where the Brethren views spread at the beginning of the seventeenth century. Established as a humanist gymnasium by Philipp Melanchthon in 1526 in Nuremberg, it was moved to Altdorf in 1575 and reorganized according to the model of the hochschule in Strasburg. Three years later the Emperor Rudolph II promoted the school to the status of a semi-universitas, which finally received university privileges in 1622, except for the Faculty of Theology, which received the same privileges only in $1692 .{ }^{26}$ After 1575, students came from all the Lutheran territories of the Empire, as well as from nearby countries, such as Hapsburg Bohemia and Silesia, and, more importantly, the Polish-Lithuanian Commonwealth. ${ }^{27}$ However, it was not the Polish students who introduced the Brethren's ideas into the Academy, but rather one of its professors, Ernst Soner.

Ernst Soner (1572-1612) was the son of a Lutheran merchant in Nuremberg and studied philosophy and medicine at the Academia Norica. After completing his studies, he started a long academic journey that eventually brought him into contact with Andrzej Wojdowski (1565-1622) and Christopher Ostorodt (c.1560-1611) in 1598, two Brethren missionaries. Their preaching and the books they were carrying with them succeeded in persuading Soner to embrace anti-Trinitarian beliefs. Soner went back to Altdorf in 1605 to lecture in philosophy 
and medicine at the Academia Norica. From 1605 to his death, he became the leading intellectual promoting anti-Trinitarian views in Germany. While in Altdorf, he established a circle of crypto-Socinians, which would be discovered only after his death, and converted two of the most famous non-Polish Brethren, that is, Crell and Marcin (or Martin) Ruar (15891657). ${ }^{28}$ The presence of an anti-Trinitarian group of students in Altdorf became publicly known in 1615 and in 1616. The students Johannes Vogel and Joachim Peuschel were condemned as the leading figures of the anti-Trinitarian circle in Altdorf and many of Soner's books and manuscripts were publicly burned. ${ }^{29}$

The significance of Soner's role in the development of Brethren views is unquestionable. At the same time, there is no doubt that the young Brethren came into contact with other scholars teaching at Altdorf. This is what, for instance, Crell's biographer emphasized when recalling Crell's time at the Academia Norica, mentioning several famous intellectuals who had a decisive role in Crell's education:

Altdorf was then blessed by a number of men renowned for their doctrine ... Who does not know those great names of the Republic of Letters, Taurellus the philosopher, Scipione Gentili the jurist, Rittershausen the philologist? Who does not know Piccart the logician, Praetorius the mathematician and friend of the noble Dudith, Soner the most excellent natural philosopher and physician, Virdungus the poet, Queccius the professor of ethics? ${ }^{30}$

For the purpose of this paper, Scipione Gentili (1563-1613), Konrad Rittershausen (15601613), and Michael Piccart (1574-1620) deserve special attention. Besides their expertise in law, Rittershausen and Gentili were renowned philologists, something that might have attracted 
students like Crell, who studied philology and ancient languages (Greek and Hebrew) in Altdorf. Gentili particularly applied philology to the study of the corpus iuris. ${ }^{31}$ Moreover, he never discussed theological matters and never subscribed to a confession of faith, something that might hint at latitudinarian views in religion that the anti-Trinitarians would have certainly appreciated. ${ }^{32}$ This is likely the reason why the German philologist Thomas Crenius suggested Gentili's alleged heterodoxy, reminding his readers that Gentili taught at Altdorf exactly when Socinianism was spreading. ${ }^{33}$ A few years later, the Lutheran theologian Gustav Georg Zeltner claimed that these accusations were unfounded, but one of Gentili’s students, Johann Gerard Frauenburger, did indeed belong to the anti-Trinitarian circle in Altdorf. ${ }^{34}$ Frauenburger would then become professor of law at Altdorf in 1618 and publish a disputation on warfare in $1630 .^{35}$ Finally, Piccart's interest in Aristotelianism was shared by the circle of people around Soner. In 1609, Soner began giving private lectures on Aristotle’s metaphysics to some students and many anti-Trinitarian students participated in these lectures. ${ }^{36}$ Therefore, it is not surprising that 'in the writings of Crell can be seen a blend of Socinianism, Protestant Aristotelianism and concepts derived from Roman law'. ${ }^{37}$ In Altdorf, Gentili, Rittershausen, and Piccart also discussed the ius belli. Gentili and Piccart published two disputations on the legitimacy of warfare in 1599 and 1618, while Rittershausen published a disputation on the ius civilis that included also some theses on the ius belli in 1611. Lectures and disputations were the two principal modes of instruction in early modern university. Disputations were formal debates in which students sustained, attacked, or defended a question set by the professor, using the resources provided for them by the professor's lectures. They were 'used as part of the regular curriculum, taking place weekly and in some cases even daily’. ${ }^{38}$ Therefore, these disputations on the ius belli were well known among the students, including the anti-Trinitarians and young Brethren enrolled in the Academia Norica in those years. In the following, I focus only on 
Gentili and Rittershausen, as Piccart's disputation is almost identical in structure and content to Gentili’s. ${ }^{39}$

In the 'Disputation on the Law of War', Gentili defines a war as a just fight between two equals. ${ }^{40}$ Therefore, there can be a war only between sovereigns or free nations, which should be waged only when there is no other way of resolving disputes. Only necessity can bring forth a war. ${ }^{41}$ Moreover, a war is just only if its causes and the way in which is waged and carried out are just. ${ }^{42}$ 'A most just cause of war is defense', Gentili writes, 'and this is threefold, necessary, useful, and honest' ${ }^{43}$ Defense is necessary when people are assailed or a war is declared and prepared by enemies. Defense is useful when someone fears being oppressed by another, while it is honorable when someone without any fear of danger helps someone else because of the natural fellowship among people. Rather, Gentili adds, everyone is bound to defend another, especially a neighbor or an ally. ${ }^{44}$ This means that it is legitimate to help the subjects of another country against their ruler, 'and it is more legitimate, if they, friends or neighbors, are forced by a tyrannical power' ${ }^{45}$ As for religious wars, Gentili regards as unjust those wars waged to compel a nation or some people to a religion, even if it is a most just cause of war to defend religion against the impious. ${ }^{46}$ Gentili never mentions the natural law vim vi repellere, but there is no doubt that his emphasis on defense as a just cause of war relies on it. In one of the 'Annotations on Torquato Tasso’s Gerusalemme liberata', Gentili writes that 'no law is more holy than that of nature, which orders us to defend our well-being and faculties from the force and wrongdoing of enemies'. ${ }^{47}$

Gentili’s assertions on the legitimacy of intervening in defense of other countries seem to allow people to resist their ruler, especially if she or he is a tyrant. This is how, for instance, Cornel Zwierlein has interpreted these statements. ${ }^{48}$ On the other hand, in his examination of Gentili’s 'Annotations', Alberto Clerici has argued that Gentili seemed to favor a third way between those defending absolute obedience to a ruler and those defending the right to resist a 
tyrant: it is not legitimate to take arms against a sovereign, but it is legitimate to ask for help from foreign sovereigns in order to overthrow a tyrant. ${ }^{49}$ Gentili's 'Disputation' strengthens this interpretation and places him in a broader European debate on the right of states to intervene in one another's affairs. ${ }^{50}$ Indeed, Gentili openly writes that private people cannot 'move a war or make peace without a public decree', reinforcing the idea that this is akin to laesa majestas, while regarding as legitimate the defense of other nations and people against a tyrant. $^{51}$

Rittershausen did not openly discuss the ius belli, but there are some references on the topic of warfare and its legitimacy in his 'Theses on the Civil Law', discussed in the Academy and published in $1611 .^{52}$ According to Rittershausen, there are supreme and lesser magistrates, the former having the supreme power in the commonwealth, the latter holding less important offices. ${ }^{53}$ The supreme magistrate has the right to declare and put an end to wars, among other prerogatives. ${ }^{54}$ In this thesis, Rittershausen briefly discusses the topic of warfare, without entering into much detail and just quoting a series of scholars who treated this topic more thoroughly, including Alberico Gentili. ${ }^{55}$ Then, Rittershausen proceeds in answering a question that was particularly relevant for the Brethren: 'whether all who have been summoned by the sovereign are bound to go to war'. 'According to the Roman law', Rittershausen writes, 'almost all people ... were compelled to the military service and it was regarded as a major crime to refuse duty of the military service'. As for the present time, however, Rittershausen distinguishes two cases: when 'a realm is invaded and there are not enough soldiers' and when, on the contrary, soldiers are sufficient to defend the country. In the first case, 'all who are suitable can be compelled to the military service', while in the other case 'only the nobles and those who have a knight's fee are obliged to this service'. All other citizens can pay taxes and tributes to avoid going to war. ${ }^{56}$ For the Brethren reading this thesis, this meant that at least the 
members of the gentry had a legal duty to defend their country when invaded. As for religious wars, Rittershausen rejects the very idea of religious warfare as Gentili did. ${ }^{57}$

When considering the broader sixteenth- and seventeenth-century debate on the ius belli or the ius gladii, it is clear that Gentili's and Rittershausen's position was not particularly original. Rather, they defended views on the legitimacy of warfare and of religious defensive wars consistent with the standard Lutheran approach to these topics as developed, for instance, by Melanchthon. ${ }^{58}$ While not particularly innovative form a Protestant point of view, Gentili's and Rittershausen's ideas were certainly original for the young Brethren studying in Altdorf. Crell, Przypkowksi, and Szlichtyng stayed in the German Academy in different times between 1606 and 1616. Szlichtyng spent only a few months in Altdorf, arriving in 1616 when the 'Socinian scandal' was reaching his peak, but Crell, his friend and mentor, stayed in Altdorf from 1606 to 1613. In 1616, Szlichtyng and Przypkowski, who was at the Academy since 1614, moved to Leiden, before returning in Poland. ${ }^{59}$ The new generation of Brethren thus certainly knew the views of Gentili and Rittershausen. The ideas on magistracy and warfare that Crell, Szlichtyng, and Przypkowski personally encountered at Altdorf undoubtedly gave them a new awareness of the debates on the ius belli and ius gladii which certainly contributed to a revision of the Brethren approach to politics and religion.

\section{III}

By the late 1610s and beginning of the 1620s, many of the first spokespersons among the Brethren were dead: Socinus died in 1604, Ostorodt in 1611, Smalcius in 1622, Moskorowski in 1625. A new generation of scholars was ready to take over the leadership of the Minor

Church. Crell was one of the leading figures among the Brethren in the 1620s. After leaving 
Altdorf in November 1613, Crell moved to Poland and reached Raków, where he stayed until he died in 1633. In 1616, he became the rector of the Racovian Academy. ${ }^{60}$

Crell had developed a different attitude towards the secular magistrate and the duties of Christians as citizens by 1623, when he published his reply to the Dutch jurist Hugo Grotius, who had attacked Socinus's opinions on the doctrine of Christ's satisfaction. ${ }^{61}$ According to Sarah Mortimer, Crell 'needed also to reassure his readers that Socinus's views did not undermine civil government' and thus, he 'included a lengthy explanation of the origins of legitimate government' ${ }^{62}$ Crell argued that each individual has a natural desire based on one’s anger to harm those who had harmed us, which gives rise to a natural and individual ius gladii. ${ }^{63}$ This right does not compel one to act in a specific way, because rights are instruments, not duties, to be used as the owner sees fit. ${ }^{64}$ As long as the punishment does not exceed the injury received, the ius gladii is 'in itself neither good nor bad but rather a tool which could be used rightly or wrongly'. ${ }^{65}$ The law of proportion between injury and punishment is thus fundamental in Crell's thinking. Crell proceeded then to argue that men and women chose to yield their right of punishment and to live under a ruler, believing that a settled government would be in their own best interests. In other words, 'government was set up on utilitarian grounds, based upon an act of consent'. ${ }^{66}$ This also means that the magistrate's ius gladii originates from the natural right of each person living inside the community and, therefore, he or she is allowed to use it as he sees fit, as long as the punishment does not exceed the crime. ${ }^{67}$

Crell defended this conclusion in his lectures on Romans delivered during his time at Raków. ${ }^{68}$ Lecturing on Romans 13.1, Crell put forward three ideas: all people (be they Christian or not) must obey 'those who have the authority or the right to govern others'; obedience must be absolute, as long as the civil authorities do not command something against God's order, in which case 'one should obey God rather than the magistrate'; magistrates receive their authority from God, because 'all authority comes from God' ${ }^{69}$ Reading Romans 
13.4, Crell emphasizes again an unconditional obedience toward the magistrate: '[The magistrate] is God's minister for you in good. Therefore, you must submit to the authority ... no one is appointed as God's ministers if not by God's authority and will' ${ }^{70}$ On the other hand, if secular authority comes from God, Christians can then hold public offices as well. Indeed, in his own commentary to Romans, written in the last years of his life, Szlichtyng openly rejects the arguments of those stating that Christians cannot hold public offices and writes that, on the contrary, no one is better suited to be a ruler: 'who will keep Christians from this duty', Szlichtyng asks rhetorically, 'and will not rather ask through prayers either that all kings become Christian or all Christians become kings? ${ }^{71}$

Revising the more moderate views of those Brethren who allowed Christian magistrates so long as they refrained from killing or severely wounding anyone, Crell argues for an ius gladii that includes all kinds of punishments, even the death penalty:

[The magistrate] does not bear the sword in vain. Not at leisure, without purpose, without deliberation, and in vain. The sword is the means of punishment, and the death penalty is the most common means. Therefore, according to jurists and common speech, the right or authority of the sword is understood as the authority to inflict the death penalty ... all kinds of punishments are tacitly included under the sword ... these words of the Apostle wanted wrongdoers and those who are refractory to the magistrates to fear the punishment. And he added: [the magistrate] is God's minister, so that no one would think that the magistrate inflicts this [punishment] by his own authority or even the consent of people. ${ }^{72}$ 
Interpreting the same passage, Szlichtyng agrees with Crell and writes that 'the magistrate has also the right and authority of punishing through the sword, that is, of killing criminals', because the sword 'is the means to behead and kill a man'. And the magistrate could not accomplish his office 'without the right and authority of the sword' ${ }^{73}$ Szlichtyng had already developed these ideas in his reply to the German theologian Balthasar Meisner in $1636 .{ }^{74}$ Without denying that Christ's precepts are universal and thus bind all Christians, Szlichtyng argues that the status of a magistrate, either supreme or lesser, differs from that of private Christians, as the magistrate received his office from God, including the ius gladii, which is entrusted to the magistrate by God together with the office. Therefore, the magistrate is still bound to follow Christ's precept to love both one's neighbour and enemy, but this does not mean that he cannot exercise his ius gladii, but rather that he should use moderation in his duties. ${ }^{75}$ However, the magistrate's office and duties include defending the innocents and punishing those who are dishonest, and consequently he must punish criminals, even with the death penalty, as long as the punishment does not exceed the crime. ${ }^{76}$

Neither Crell nor Szlichtyng restrained the rights and duties of civil offices within a commonwealth. Szlichtyng went even further by examining whether Christians go against God's laws when participating in defensive wars. Distinguishing necessary defence into private and public, the latter being the war waged by the legitimate magistrate, Szlichtyng states that Socinus did not disapprove warfare broadly conceived, but only those wars waged by private persons:

Although he [Socinus] indeed disapproves war, that is, the repelling of enemies connected with their death, and he says that it is contrary to Christ's precepts, he does not speak, however, of the war or slaughter of invading enemies that the 
magistrate carries through to preserve the commonwealth, after hiring soldiers for this matter; but [he speaks of the war] that Christians begin spontaneously, allowing themselves to be hired for and employed in such a war voluntarily. ${ }^{77}$

Socinus actually condemned warfare broadly conceived, but Szlichtyng uses Socinus's name to put forward his own ideas as if they had always been the Brethren's mainstream opinion on defensive wars. If Socinus/Szlichtyng believes that wars waged by the magistrates to preserve the commonwealth are not contrary to Christ's precepts, it is clear that Christian magistrates can wage such defensive necessary wars. Szlichtyng rejects almost all causes of just war listed by Meisner, especially those related to religion. ${ }^{78}$ After all, the Christian magistrate is bound to love even his enemies and thus he should avoid waging war as much as he can. ${ }^{79}$ However, if the very existence of the commonwealth is at stake, then even the Christian magistrate is allowed to wage a defensive war. Mentioning 'the repelling of servitude and violence, the preservation of freedom, life, and public peace' as goals that should be pursued through a war, Szlichtyng does not deny them, 'because we Brethren do not dispute the war begun by the magistrate for public security because of a pressing necessity'. ${ }^{80}$ Arguing that even nonChristian authors allowed fewer just causes of war than Meisner did, as they usually regarded only the repelling of force and the defence of oneself and one's relatives, the claiming of stolen goods, and the revenge for offences as just causes of wars, Szlichtyng urges Christians merely to act with moderation and try to avoid wars as much as possible. ${ }^{81}$

If Christian magistrates are allowed to wage wars in certain circumstances, private Christians can also participate in these same wars as long as they do not do so voluntarily. As stated in the passage quoted above, Socinus/Szlichtyng only rejected those wars that 'Christians begin spontaneously, allowing themselves to be hired for and employed in such a war 
voluntarily'. The Latin words sponte and ultro, 'spontaneously' and 'voluntarily', are the conditions that make this participation illegitimate. Indeed, when discussing Meisner's argument for necessary defensive warfare based on the natural law vim vi repellere, Szlichtyng writes that 'we Brethren do not argue anything against this argument', if it is used to argue for 'the war undertaken by the magistrate against a public enemy'. Szlichtyng only denies that this natural law can be used to defend those wars that 'private persons join spontaneously and voluntarily'. ${ }^{82}$ And again, discussing Meisner's arguments based on the evidence from the Church Fathers, Szlichtyng states that those passages 'are by no means contrary to us, because they treat the wars began by the magistrate for the public safety'. 'We', Szlichtyng continues, 'blame those who, while being Christians, enlist voluntarily in the military service and devote their effort to the killing of enemies'. ${ }^{83}$ Therefore, it can be assumed that Christians are allowed to go to war when following the legitimate magistrate's command. Rather, since all people must always obey their magistrate, they must follow her or him in war when ordered to do so. In Quaestiones duae, Szlichtyng does not expand on his theory of legitimate warfare, but it seems that the divine office of magistracy provides such a legitimacy. All Christians are bound to follow Christ's precept to love one's enemy, but it is nevertheless licit for Christian magistrate to wage defensive war, because they received their office from God and this includes the protection of the commonwealth. And even if private Christians are bound to the same love, they are also bound by divine law to an absolute obedience towards the magistrate and this allows them to participate in defensive wars. Magistracy and obedience to magistracy create an exception to that divine law prescribing universal love, rather than contradicting it, and thus they provide legitimacy to necessary defensive warfare. ${ }^{84}$

Despite Crell's and Szlichting's far-reaching attempt of revising the history of the Brethren's approach to magistracy and warfare, the pacifist wing of the Minor Church continued to attract adherents, as proven by the controversy in the late 1640s between 
Szlichtyng and Johann Ludwig von Wolzogen (1599-1661), an Austrian noblemen and member of the Brethren who re-stated the original pacifist views of the Minor Church. However, the pacifist wing gradually became the minority among the Brethren. The last edition of the Racovian Catechism provides evidence of this. ${ }^{85}$ The text of this edition is the same published in 1665, which included revisions made by Crell, Szlichtyng, and likely others, but in 1684, the editors added some notes to explain passages of the Catechism. In one of the passages emphasizing the legitimacy of magistracy, Benedykt Wiszowaty (c.1650-c.1704), great-grandson of Socinus and sharing the pacifism of his great-grandfather, added a note explaining that the first leaders of the Minor Church held quite different views on magistracy and that for Christians would be better 'to relinquish civil magistracy to the men of this world' and 'to refrain from usurping for themselves the right of exercising authority over others, and much more of shedding human blood' ${ }^{86}$ Wiszowaty was aware, however, that the pacifists had been a minority for a long time, stating that Szlichtyng 'with many of his contemporaries, members of these churches, was of a contrary opinion' ${ }^{87}$

\section{IV}

In conclusion, solid evidence proves that Crell and Szlichtyng had changed their views on politics and religion before the mid-seventeenth century. Answering the three questions raised at the beginning of this paper, Crell and Szlichtying would have replied that: it is legitimate for Christians to hold public offices, because in doing so they fulfil God's will; it is legitimate for Christian magistrates to make use of their ius gladii, even by inflicting the death penalty, as long as they use Christian moderation and there is a rightful proportion between crime and punishment; it is also legitimate for Christian magistrates to wage defensive war when the safety of the commonwealth and its people is at stake, as long as there is no other means to 
avoid this war and to save one's country; finally, it is legitimate for private Christians to participate in defensive wars, as long as they do not do so voluntarily, but compelled by their lawful sovereign and necessity. When examining the controversy between Szlichtyng and Wolzogen in the late 1640s and 1650s, Kot showed that Szlichtyng defended these same ideas. ${ }^{88}$ Kot, however, failed to notice that Crell and Szlichtyng had already developed them in the years between 1623 and 1636, during the Thirty Years War, not afterwards. ${ }^{89}$

I have also suggested two reasons that can explain why Crell and Szlichtyng to moved away from the original pacifism of the Minor Church. The first is the almost continuous warfare that characterized the history of the Polish-Lithuanian Commonwealth in the first decades of the seventeenth century. As citizens of the Commonwealth and active members of the king's court, noblemen and gentry men belonging to the Minor Church strived to defend their estates and their country, and thus they wished to conciliate their faith with the holding of public offices and the participation of wars. This was required even more since Polish Catholics also attacked the Brethren for their socio-political ideas, as well as for their theological beliefs. Therefore, I do agree with Kot and Tazbir in seeing the historical wars fought by the Commonwealth as one of the reasons behind the Brethren's changed view, but instead of referring to the Cossack invasions in the early 1650s, I regard the much earlier attacks by the Tatars and the Turks, and the wars against Sweden and Muscovy in the 1620s and 1630s as the historical events pushing the Brethren to more lenient views on magistracy and warfare. ${ }^{90}$

The second suggested reason is the openness of the second-generation of Brethren towards the European intellectual world, as young Brethren began studying in different universities and academies across Europe. I have focused on the Lutheran Academy of Altdorf, as it was the most famous institution where young Brethren carried out their higher education until the mid-1610s. Relevant literature on the history of the Brethren stressed the significance of this Academy mainly because of the leading German anti-Trinitarian of the time teaching in 
Altdorf, Ernst Soner. I have further revealed that other intellectuals lecturing at the Academia Norica had a likely impact on the young Brethren's education as well, focusing on Gentili's and Rittershausen's disputations on the ius belli and ius gladii. These were not particularly innovative within the Protestant tradition, but they undoubtedly made Brethren such as Crell and Szlichtyng aware of the European debates on magistracy and warfare in a critical period when they were facing a range of practical political and military issues, and needed to reach for ideas different from those of their church. Crell and Szlichtyng would then take active part in such debates. Indeed, Crell began reshaping his ideas on magistracy when defending Socinus from Grotius’s criticisms, while Szlichtyng took a different stand on warfare when replying to Balthasar Meisner.

This clearly proves that their education outside Poland and the very debates held with intellectuals belonging to other confessions gradually led the Brethren to revise the doctrines on magistracy and warfare advocated by their forefathers, and to reach a position that cannot be defined as standard among Protestants, but that was certainly closer to the mainstream Protestant approach to politics and warfare than the pacifism of the first Brethren. Szlichtying's ideas on the legitimacy of defensive wars and of the non-voluntary participation of private Christians in them, for instance, are somewhat similar to those developed by intellectuals such as Lambert Daneau, Gulielmus Becanus, Johann Alsted, Hugo Grotius, and Johannes Hoornbeeck. Indeed, his assertions seem related to the doctrine of absolute obedience to sovereign authority that much characterized the Protestant thinking on warfare. ${ }^{91}$ The concept of the non-voluntary participation in wars seem to be part of the debates on the use of mercenary service as well. ${ }^{92}$ A comparative analysis of Szlichtyng's and other Brethen's views with the broader European debates on the ius belli and ius gladii is beyond the scope of this paper. Such an analysis, however, would undoubtedly have valuable outcomes. Kot and Tazbir, for instance, thought that Szlichtyng's ideas against mercenary service were a result of the 
aftermath of the Thirty Years War, but I have revealed that he had developed the central core of such ideas during the Thirty Years War and thus, an examination of how European intellectuals reacted to Crell's and Szlichtyng's new ideas on magistracy and warfare in this crucial period for European history would be undoubtedly beneficial. More broadly, such an examination might also contribute to contemporary debates on just war theory. Recent developments include the ideas that defensive war is not morally distinctive from individual self-defence or that it is morally wrong to fight in a war that is unjust. ${ }^{93}$ Although there are profound differences between the past and present discussions on the ius belli, Szlichtyng would certainly agree with such views and he would add that it is also morally wrong to voluntarily fight in a war that is just. Indeed, as early as the 1620 s and 1630s, Crell and Szlichtyng developed and disseminated a position between the legitimacy of warfare and pacifism that can be regarded as a form of what today is called 'contingent pacifism' ${ }^{94}$ Recovering these debates from a not-so-distant past might also provide contemporary scholars with new food for thought.

Queen’s University Belfast, University Road, Belfast, BT7 1NN. F.Quatrini@qub.ac.uk

* The research upon which this article is based was conducted as part of research project War and the Supernatural in Early Modern Europe, funded by the European Research Council under the European Union's Horizon 2020 research and innovation programme (grant agreement number no. 677490). I would like to thank Ian Campbell, Crawford Gribben, Floris Verhaart, and the two journal reviewers for their comments and suggestions.

${ }^{1}$ Vincenzo Lavenia, Dio in uniforme. Cappellani, catechesi cattolica e soldati in età moderna (Bologna, 2017), p. 19 and 37-79. For more information on just war theories in early modern Europe see Peter Haggenmacher, Grotius et la doctrine de la guerre juste (Geneva, 1983); Richard Tuck, The Rights of War and Peace. Political Thought and the International Order from Grotius to Kant (Oxford, 1999); Michael Becker, Kriegsrecht im frühneuzeitlichen Protestantismus: Eine Untersuchung zum Beitrag lutherischer und reformierter Theologen, Juristen un anderer Gelehrter zur Kriegsrechtsliteratur im 16. and 17. Jahrhundert (Tübingen, 2017); 
Daniel Schwartz, The Political Morality of the Late Scholastics. Civil Life, War, and Conscience (Cambridge, 2019), pp. 119-207.

${ }^{2}$ Robert von Friedeburg, Self-Defence and Religious Strife in Early Modern Europe. England and Germany, 1530-1680 (Aldershot, 2002); Harro Höpfl, Jesuit Political Thought. The Society of Jesus and the State, c. 1540-1630 (Cambridge, 2004), pp. 314-338.

${ }^{3}$ Andrew Fiala, 'Pacifism', The Stanford Encyclopedia of Philosophy (Fall 2018 Edition), Edward N. Zalta (ed.), URL = https://plato.stanford.edu/archives/fall2018/entries/pacifism.

${ }^{4}$ In the following, I will rarely refer to the Brethren as Socinians, as this was the name given them by opponents outside the Polish-Lithuanian Commonwealth. For the role of Socinus, see Stanislas Kot, Socinianism in Poland. The Social and Political Ideas of the Polish Antitrinitarians, transl. Earl Morse Wilbur (Boston, 1957), pp. xix and 82-96; Domenico Caccamo, Eretici Italiani in Moravia, Polonia, Transilvania (1558-1611) (Firenze, 1999), pp. 153-173; Sarah Mortimer, Reason and Religion in the English Revolution. The Challenge of Socinianism (Oxford, 2010), pp. 2-3 and 13-22. For the use of the name Brethren and Socinians, see George Hunston Williams, Introduction to History of the Polish Reformation and Nine Related Documents, transl. by George Hunston Williams (Minneapolis, 1995), p. 11; Piotr Wilczek, Polonia Reformata. Essays on the Polish Reformation (Göttingen, 2016), p. 39.

${ }^{5}$ Kot, Socinianism in Poland, pp. 143-145 and 171-181; Janusz Tazbir, 'Pacifism in the Ideology of the Polish Brethren', Polish Western Affairs 15 (1974), pp. 200 and 215; Peter Brock, 'Dilemmas of a Socinian Pacifist in Seventeenth-Century Poland', Church History 63 (1994), pp. 191 and 192-199.

${ }^{6}$ For Crell's, Szlichtyng's, and Przipkowski's biographies, see Robert Wallace, Antitrinitarian Biography: or Sketches of the Lives and Writings of Distinguished Antitrinitarians (London, 1850), II, pp. 558571, and III, 20-39 and 39-58; Maciej Ptaszyński, 'Jonasz Szlichtyng (1592-1661) - The Forgotten Arian Theologian of the 17th Century?' in Polish Baroque, European Contexts. Proceeding of an International Seminar Held at the Institute for Interdisciplinary Studies 'Artes Liberales', University of Warsaw, June 27-28, 2011, ed. Piotr Salwa (Warsaw, 2012), pp. 163-182.

${ }^{7}$ Mortimer, Reason and Religion, pp. 23-24. See also Sarah Mortimer, 'Human Liberty and Human Nature in the Works of Faustus Socinus and His Readers', Journal of the History of Ideas 70 (2009), pp. 203-204.

${ }^{8}$ For an account of the Reformation in Poland, see Wojciech Kriegseisen, 'Historical Overview of the Political and Denominational Reality in the Polish-Lithuanian Commonwealth from the Mid-Sixteenth Century to the Mid-Seventeenth Century' in Word of God, Words of Men: Translations, Inspirations, Transmissions of the 
Bible in the Polish-Lithuanian Commonwealth in the Renaissance, ed. Joanna Pietrzak-Thébault (Göttingen, 2019), pp. 19-38. For more information on the beginnings of the Polish Minor Church and its relation with Italian exiled communities in east Europe, see Earl Morse Wilbur, A History of Unitarianism. Volume I: Socinianism and its Antecedents (Boston, 1977-1978), I, pp. 281-430; Kot, Socinianism, pp. ix-xxi, 1-8, and 31-49; Williams, 'Introduction’, 25-65; Delio Cantimori, Eretici italiani del cinquecento (Turin, 2009), pp. 205-246 and 312-418. The origins of the Minor Church, however, are still not perfectly clear. Indeed, Piotr Wilczek has recently highlighted how new research on the history of the Brethren based on both primary and secondary sources is much needed. Wilczek, Polonia Reformata, pp. 36-44. The research project 'Die Sozinianischen Briefwechsel. Zwischen Theologie, Frümoderner Naturwissenschaft und Politscher Korrespondenz’ might soon provide new significant evidence.

${ }^{9}$ Kot, Socinianism, p. xxxiii; Wilczek, Polonia Reformata, pp. 45-55.

${ }^{10}$ Mortimer, Reason and Religion, p. 38.

${ }^{11}$ Magdalena Luszczynska, for instance, has described three main and somewhat opposing groups in the early years of the Minor Church. Magdalena Luszczynska, Politics of Polemics: Marcin Czechowic on the Jews (Berlin, 2018), pp. 5-6.

${ }^{12}$ Mihály Balázs, Early Transylvanian Antitrinitarianism (1566-1571): From Servet to Palaeologus (Baden-Baden, 1996).

${ }^{13}$ Janusz Tazbir, 'Polish Defenders of Political and Religious Peace in the 16th and 17th Centuries', Dialectics and Humanism 9 (1983), p. 258. See also Kot, Socinianism, p. 52; Mortimer, ‘Human Liberty’, p. 195.

${ }^{14}$ For detailed accounts of Socinus's ideas about politics and warfare, see Kot, Socinianism, pp. 82-96; Cantimori, Eretici italiani, pp. 407-413.

${ }^{15}$ Kot, Socinianism, pp. 112-115.

${ }^{16}$ Valentin Smalcius, Refutatio thesium D. Wolfgangi Frantzii, Theologiae Doctoris et Professoris publici in Academia Witebergensi, quas ibidem De praecipuis christianae religionis capitibus anno 1609 et 1610 disputandas proposuit (Rákow, 1614).

17 'Et ne quis statuat, hac ratione aliquid detrahi magistratui, sciendum est, nos, qui credimus, non licere magistratui christiano sanguinem humanum fundere, ut hodie fit, credere, quod aliis modis, qui fortassis sunt severiores, quam sanguinis fusio, in officio continere liceat magistratui homines facinorosos, modo ne vita priventur'. Ibid., p. 389. 
18 'In quarta sectione directe nos petit, et bella gerere, licere affirmat, quod nos negamus et indignum Christiana pietate esse contendimus’. Ibid., p. 393.

${ }^{19}$ Ibid., p. 394. Christopher Ostorodt, another prominent member of the Minor Church at the time, put forward the same ideas. Kot, Socinianism, pp. 124-126; Tazbir, 'Pacifism’, p. 213.

${ }^{20}$ Robert I. Frost, The Northern Wars. War, State, and Society in Northeastern Europe, 1558-1721 (Harlow, 2000), pp. 74, 77, 91, and 150.

${ }^{21}$ Ibid., pp. 104-114 and 142-147.

${ }^{22}$ Ibid., pp. 89-90. Joanna Kostylo has highlighted how the anti-royalist faction drew on Venetian republican ideologies to justify their resistance against their sovereign. Joanna Kostylo, 'Commonwealth of All Faiths: Republican Myth and the Italian Diaspora in Sixteenth-Century Poland-Lithuania', in Citizenship and Identity in a Multinational Commonwealth. Poland-Lithuania in Context, 1550-1772, ed. Karin Friedrich and Barbara M. Pendzich (Leiden, 2009), pp. 172-177.

${ }^{23}$ Ibid., pp. 203-204.

${ }^{24}$ Kot, Socinianism, pp. 138-139.

${ }^{25}$ Tazbir, ‘Pacifism’, pp. 214.

${ }^{26}$ Martin Schmeisser and Klaus Birnstiel, 'Gelehrtenkultur und Antitrinitarische Häresie an der Nürnberger Akademie zu Altdorf', Daphnis 39 (2010), pp. 229-232. For a detailed history of the Academia Norica between 1575 and 1623, see Wolfgang Mährle, Academia Norica. Wissenschaft und Bildung an der Nürnberger Hohen Schule in Altdorf (1575-1623) (Stuttgart, 2000).

${ }^{27}$ Ibid., pp. 86-87.

${ }^{28}$ The term of crypto-Socinianism is taken from Gustav Georg Zeltner, who wrote the first account of the spread of the Brethren's views in Altdorf. Gustav Georg Zeltner, Historia crypto-socinismi Altorfinae quondam academiae infesti arcana (Leipzig, 1729). More recent studies include Siegfried Wollgast, Philosophie in Deutschland zwischen Reformation und Aufklärung 1550-1650 (Berlin, 1988), pp. 346-422; Ralf Bröer, 'Antiparacelsismus und radikale Reformation. Ernst Soner (1573-1612) und der Sozinianismus in Altdorf', Odrodzenie i Reformacja w Polsce 48 (2004), pp. 117-147; Ralf Bröer, 'Antiparacelsismus und Dreienigkeit. Medizinischer Antitrinitarismus von Thomas Erastus (1524-1583) bis Ernst Soner (1572-1605)', Berichte zur Wissenschaftsgeschichte 29 (2006), pp. 137-154; Schmeisser, ‘Gelehrtenkultur und Antitrinitarische Häresie’, pp. 222-285; Martin Schmeisser, Sozinianische Bekenntnisschriften. Der Rakówer Katechismus des Valentin Schmalz (1608) und der sogenannte Soner-Katechismus (Berlin, 2012), pp. 57-78. 
${ }^{29}$ Soner's students managed to save some of his manuscripts, including a catechism similar in both structure and content to the famous Racovian Catechism. See Schmeisser, 'Gelehrtenkultur und Antitrinitarische Häresie’, pp. 236-253; Wolfgang Mährle, ‘Eine Hochburg des “Kryptocalvinismus” und des “Kryptosozinianismus”? Heterodoxie an der Nürnberger Hochscule in Altdorf um 1600’, Mitteilungen des Vereins für Geschichte der Stadt Nürnberg 97 (2010), pp. 117-150. Martin Schmeisser has recently transcribed and published Soner’s catechism. Schmeisser, Sozinianische Bekenntnisschriften, pp. 215-360.

30 'Beatum tunc erat Altorfium virorum doctrina celebrium proventu ... quis ignorat magna illa Reipublicae literariae nomina, Taurellum philosophum, Scipionem Gentilem juris consultum, Rittershusium philologum? Quis Piccartum logicum, Praetorium mathematicum, et magni illius Dudithii familiarem, quis Sonerum physicum et medicum praestantissimum, Wirdingum poëtam, Queccium ethicae professorem?' 'Vita Joannis Crellii Franci a J. P. M. D.', in Joannis Crellii Franci Opera omnia exegetica. Sive ejus in plerosque Novi Testamenti libros commentarii. Maximam partem hactenus inediti (Eleutheropoli, 1656), II, p. *1v.

31 ‘Vita Joannis Crellii Franci’, p. *1v. In Altdorf, Gentili was appointed in 1590 to explain the Institutes of Justinian and in 1591, he began lecturing on the Codex Justinianeus. Rittershausen began teaching in Altdorf in 1591, being appointed to lecture in Justinian’s Digest and Institutes. They were the two most prominent jurists in Altdorf. Mährle, Academia Norica, pp. 445-450, 429-437, 443-444, and 463. For Gentili’s background in literature, and his interest in poetics and philology applied to the study of law, see Francesco Ferretti, “"Picenus hospes”. Scipione Gentili interprete europeo della "Gerusalemme liberata”, in Alberico e Scipione Gentili nell'Europa di ieri e di oggi. Reti di relazioni e cultura politica, ed. Vincenzo Lavenia (Macerata, 2018), pp. 20, 27, and 38-39; Cornel Zwierlein, 'Scipione and Alberico Gentili on Conspiracies around 1600: Tacitean Views on the “crimen laesae majestatis”', in Alberico e Scipione Gentili, pp. 55-56 and 64-66. For Gentili’s biography, see Alberto Clerici, ““Maxima quaestio”. Scipione Gentili, Alberico Gentili e la rivolta dei Paesi Bassi (15821587)’, in Alberico e Scipione Gentili, pp. 100-105; Lucia Bianchin, 'Gentili, Scipione’, in Dizionario biografico dei giuristi italiani, ed. Italo Birocchi et al. (Bologna, 2013), pp. 969-970. For more information on Rittershausen, see Mährle, Academia Norica, pp.451-460; Thomas Duve, 'Rittershausen, Konrad', in Neue Deutsche Biographie 21 (2003), pp. 670-671; https://www.deutsche-biographie.de/pnd104288639.html\#ndbcontent.

${ }^{32}$ Zwierlein, ‘Scipione and Alberico Gentili’, 53-54.

33 Thomas Crenius, Animadversiones philologicae et historicae (Leiden, 1697-1720), XVI, pp. 340-341.

${ }^{34}$ Zeltner, Historia crypto-socinismi, p. 71; Zwierlein, ‘Scipione and Alberico Gentili’, p. 70. 
35 Johann Gerhard Frauenburger, Theses politicae de bello (Altdorf, 1630). For Frauenburger's teaching at Altdorf, see Mährle, Academia Norica, pp. 474-476.

${ }^{36}$ Mährle, Academia Norica, p. 385.

${ }^{37}$ Mortimer, 'Human Liberty’, p. 205. For an account of Soner’s Aristotelianism and its significance for the development of theological and metaphysical concepts among the Brethren, see Wollgast, Philosophie in Deutschland, pp. 381-407.

${ }^{38}$ Kenneth G. Appold, ‘Academic Life and Teaching in Post-Reformation Lutheranism', in Lutheran Ecclesiastical Culture 1550-1675, ed. Robert Kolb (Leiden, 2008), p. 104. See also: Ibid., pp. 82 and 84-85.

${ }^{39}$ Michael Piccart, Disputatio de iure belli (Altdorf, 1618). For more information on Piccart, see Mährle, Academia Norica, ch. V, passim; S. Heßbrüggen-Walter, 'Piccart, Michael', in Encyclopedia of Renaissance Philosophy, ed. M. Sgarbi (Springer, 2016), pp. 566-571; https://doi.org/10.1007/978-3-319-02848-4_566-1.

${ }^{40}$ Scipione Gentili, 'Disputatio De Jure Belli’, in Scipionis Gentilis Jurisconsulti et Antecessoris Norici Opera Omnia in Plures Tomos Distributa, (Naples, 1763-1769), I, p. 324.

41 Ibid.

${ }^{42}$ Here I will focus only on the just causes of war. For the just way to wage and carry out a war, see theses L-CV: Ibid., pp. 328-333.

43 'Justissima causa belli est defensio, eaque triplex, necessaria, utilis, et honesta'. Ibid., p. 325. In theses XXX-XXXV, Gentili lists other just causes of war, such as the prohibition of trade through seas. Ibid., pp. 326327.

${ }^{44}$ Ibid, pp. 325-326.

45 'An subditos adversus principem eorum defendere liceat quaeritur? Et magis est licere, si illi praesertim necessarii, aut vicini, impotenti imperio nimium praemantur, quamvis injusti ipsi et injustam causam habeant’. Ibid., p. 326.

${ }^{46}$ Ibid., p. 325.

47 'Perchè niuna legge è più santa di quella de la Natura, la quale ci comanda a difendere la salute e le facoltà nostre dalla forza e ingiuria de’ nemici'. Here quoted from Clerici, 'Maxima quaestio', p. 107.

${ }^{48}$ Zwierlein, 'Scipione and Alberico Gentili', p. 85.

${ }^{49}$ Clerici, ‘Maxima quaestio’, p. 110. See also pp. 106-109. 
${ }^{50}$ Richard Tuck, "Grotius, Hobbes, and Pufendorf on humanitarian intervention," in Just and Unjust Military Intervention: European Thinkers from Vitoria to Mill, ed. Stefano Recchia and Jennifer Welsh (Cambridge: Cambridge University Press, 2013), 96-112.

51 'Privatus si bellum, pacemve fecerit, sine publico scitu, capitale esse Plato voluit. Romani eum majestatis teneri. Rectissime’. Gentili, ‘Disputatio’, p. 324.

${ }^{52}$ Konrad Rittershausen, Theses de iure publico (Altdorf, 1611).

${ }^{53}$ Ibid., p. A3r.

${ }^{54}$ Ibid., p. A4r.

${ }^{55}$ Ibid., p. B1r.

56 'Num omnes evocati a principe ad bellum ire teneantur? Et quidem jure romano fere omnes ... coacti fuerunt ad militiam, et pro gravi delicto habitum detrectare munus militiae ... sed hodie distinguendum est: aut enim invaditur principatus, nec militum copia haberi potest: aut non. Priori casu omnes idonei cogi possunt ad militiam. Posteriori casu, nobiles tantum et habentes feuda militaria, obnoxia huic muneri: reliqui, principi vectigalia et indictiones solvunt, ut ab hoc munere subleventur’. Ibid., p. B1v.

${ }^{57}$ Ibid., p. B2v.

${ }^{58}$ Becker, Kriegsrecht, pp. 74-76, 106-107, 373-376, and 386-387. Further research on Gentili and Rittershausen might cast more light on if and how their views relate to the historical and political situation of Germany between the sixteenth and the seventeenth century.

59 Wallace, Antitrinitarian Biography, III, pp. 20 and 46-47; Schmeisser, Sozinianische Bekenntnisschriften, pp. 44 and 48.

60 ‘Vita Joannis Crellii Franci’, p. *2r; Mortimer, ‘Human Liberty’, p. 205.

${ }^{61}$ Johannes Crell, Ad librum Hugonis Grotii, quem De satisfactione Christi adversus Faustum Socinum Senensem scripsit, responsio (Raków, 1623).

${ }^{62}$ Mortimer, ‘Human Liberty’, p. 206.

${ }^{63}$ Ibid.

${ }^{64}$ On the legal tradition regarding the ius as a subjective right, see Brett, Liberty, pp. 123-204.

${ }^{65}$ Mortimer, 'Human liberty', p. 207.

${ }^{66}$ Ibid., p. 207.

${ }^{67}$ Ibid., pp. 207-208. 
${ }^{68}$ Johannes Crell, 'Commentarius in epistolam Pauli Apostoli ad romanos. Ex praelectionibus Johannis Crellii Franci, conscriptus a Jona de Bukowiec Schlichtingio, non tamen revisus a Crellio, praeterquam initium commentarii istius antehac editum, usque ad versum 4 capitis quarti', in Joannis Crellii Franci Opera omnia exegetica, I, pp. 65-246. One might wonder whether commenting on biblical passages led to the development of new ideas or biblical commentaries were used to introduce new concepts previously conceived. I would suggest the latter. Indeed, both Crell and Szlichtying put forward views in their commentaries that were already developed in preceding treatises. Moreover, even if they did not write a commentary on Romans 13, both Socinus and Smalcius referred to the same passages discussed by Crell and Szlichtyng to defend ideas opposite to Crell's and Szlichtyng's.

69 'Subijciatur. Hic docet, in quo officium Christianorum erga magistratum contineatur; nempe ut magitratui sint dicto audientes, et illi in omnibus obtemperent, quae divinis mandatis contraria non sunt. Nam alioqui Deus potius quam magistratus audiendus est ... Non enim est potestas nisi a Deo'. Ibid., p. 179. All italics are from the original text.

70 'Dei enim minister est tibi in bonum. Ideo te subjicere debes potestati, quia Dei minister est ... nemo enim Dei minister constituitur nisi Dei arbitrio et voluntate’. Ibid., p. 180. Crell put forward similar assertions also in his Ethica christiana. Johannes Crell, 'Ethica christiana seu explicatio virtutum et vitiorum, quorum in Sacris Literis fit mentio', in Johannis Crellii Franci Operum tomus quartum scripta ejusdem didactica et polemica complectens (Irenopoli, Post annum 1656), 435-436.

71 'Quis ab hoc munere Christianos arcebit, et non potius omnibus votis expetet, ut aut reges omnes fiant christiani, aut non alii quam christiani reges fiant?’ Jonas Szlichtyng, 'Commentarius in epistolam Pauli Apostoli ad romanos', in Jonae Slichtingii a Bukowiek Commentaria posthuma, in plerosque Novi Testamenti libros (Irenopoli, post 1656), I, p. 302.

72 'Non frustra enim gladium gestat. Non otiose, nullo fine, nullo consilio ac frustra. Gladius est instrumentum poena, et quidem capitalis, est instrumentum maxime usitatum. Unde jus vel potestas gladii apud iurisconsultos, imo et in vulgari sermone accipitur pro potestate capitali supplicio afficiendi ... sub gladio tacite comprehenduntur omnia suppliciorum genera. Quare verba apostoli id volunt, poenam esse metuendam legum transgressoribus, et magistratus refractariis. Et ne quis putaret, magistratum hoc sibi propria auctoritate, aut etiam hominum consensu sumere, subjungit: Dei enim minister est'. Crell, 'Commentarius', p. 180. This last statement does not contradict Crell's arguments in his reply to Grotius, when writing that the magistrate's right of punishment and the very commonwealth derives from the consent of people. Crell explains that magistrates are 
appointed by God's will and authority only in the sense that they are appointed and led to their duties according to a divine plan. This does not remove the need of other people's consent to form the commonwealth and give the magistrate the ius gladii.

73 ' Non frustra. Id est habet jus et potestatem etiam gladio feriendi, id est vita privandi maleficos, quorum scilicet maleficia poenam hanc mereantur. Nam, si jus et potestatem hanc magistratus non haberet, frustra omnino gladium gereret, qui instrumentum est capitis detruncandi, et hominem vita privandi. Unde autem hoc jus et potestatem habet nisi ab ipso Deo cujus minister est, praesertim cum tale ministerium gerat, quod sine gladii jure ac potestate obiri non possit’. Szlichtyng, ‘Commentarius’, p. 301.

${ }^{74}$ Jonas Szlichtyng, Quaestiones duae: una num in evangelicorum religione dogmata habeantur quae vix ullo modo permittant, ut qui eas amplectatur, nullo in peccato perseveret? Altera num in eadem religione concedantur Christi legibus inconcessa? Contra Balthasarem Meisnerum, S. theologiae doctorem et in academia Witterbergensi professorem publicum (Raków, 1636).

${ }^{75}$ Ibid., pp. 427, 433, and 436-437.

${ }^{76}$ Ibid., pp. 392-394, 440, and 444-445. See also pp. 425-426 and 434.

77 'Licet enim bellum, seu hostium propulsationem cum ipsorum nece conjunctam improbet, et Christi praeceptis contrariam esse dicat; non loquitur tamen de bello, seu hostium invadentium caede, quam magistratus ipse, conductis eam in rem militibus conservandae reipublicae causa peragit; sed quam christiani homines sua sponte suscipiunt, aut ad eam sese conduci vel adhiberi ultro sinunt’. Ibid., pp. 358-359.

${ }^{78}$ Ibid., pp. 396-399 and 407-409.

${ }^{79}$ Ibid., pp. 400-401.

80 'De reliquis finibus a te hic recensitis, qualis est depulsio servitutis ac violentiae, conservatio libertatis ... conservatio vitae et tranquillitatis publicae, de his, inquam, finibus non est quod agamus, quandoquidem de bello, a magistratu pro publica salute urgente necessitate, suscepto non disputamus’. Ibid., p. 409. See also pp. 399 and 426.

${ }^{81}$ Ibid., pp. 409-410.

82 'Argumentum a lege naturae, vim vi repellendam esse in casu necessitatis ... respondeo hoc argumentum, si concludit de bello contra publicum hostem ab ipso magistratu suscepto, nihil adversum nos concludere: si de bello, cui sese privati homines ultro et sua sponte immiscent, nihil prorsus concludere'. Ibid., pp. 375-376. 
83 'Quaquam quae affert testimonia ex Basilio, Cyrillo, Synesio, ea nobis minime sunt contraria, quippe quae de bellis agunt ab ipso magistratu pro communi salute susceptis. Nos vero nunc reprehendimos eos, qui, christiani cum sint, in militiam sponte se dant, et operam suam occidendis hostibus addicunt'. Ibid., p. 421. See also pp. 359 and 403.

${ }^{84}$ Szlichtyng might have had in mind Conradus Koellin’s distinction between licere and oportere. Brett, Liberty, pp. 113-115.

${ }^{85}$ Catechesis ecclesiarum polonicarum ... editio novissima (Spauropoli, 1684). I will quote from Thomas Rees's English translation: The Racovian Catechism, with Notes and Illustrations, Translated from the Latin, transl. Thomas Rees (London, 1818).

${ }^{86}$ Ibid., p. 178.

87 Ibid.

${ }^{88}$ Kot, Socinianism, pp. 172-181.

${ }^{89}$ Brock seemed to notice this, but then he shared Kot’s conclusion. Brok, 'Dilemmas', pp. 195-199.

${ }^{90}$ Kot, Socinianism, p. 181; Tazbir, ‘Pacifism’, pp. 216 and 218.

${ }^{91}$ Becker, Kriegsrecht, pp. 377-379.

92 Ibid., pp. 95-98 and 381-382.

93 See for instance Jeff McMahan, Killing in War (Oxford, 2009); Helen Frowe, Defensive Killing (Oxford, 2014).

${ }^{94}$ Fiala, 'Pacifism'. 